\title{
Maximal testosterone suppression in the management of recurrent and metastatic prostate cancer
}

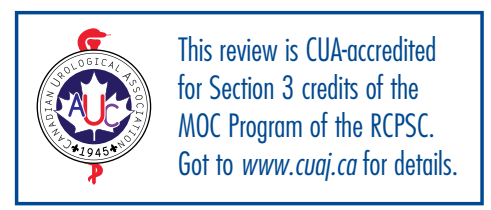

\author{
Laurence Klotz, MD, FRCSC,; Rodney H. Breau, MD, MSc, FRCSC,; Loretta L. Collins, PhD; \\ Martin E. Gleave, MD, FRCSC, FACS, Tom Pickles, MD, FRCPC, Frederic Pouliot, MD, PhD, FRCSC, ${ }^{, 6}$ \\ Fred Saad, MD, FRCSC
}

'Sunnybrook Health Sciences Centre, Toronto, ON, Canada; ${ }^{2}$ Httawa Hospital Research Institute, Ottawa, ON, Canada; ${ }^{3}$ Kaleidoscope Strategic, Toronto, ON, Canada; ${ }^{4}$ Vancouver Prostate Centre, Vancouver, BC, Canada; ${ }^{5}$ British Colombia Cancer Agency, Vancouver, BC, Canada; ${ }^{6}$ Hôtel-Dieu de Québec, Quebec City, QC, Canada; ${ }^{7}$ Centre Hospitalier de I'Université de Montréal, Montreal, QC, Canada

Cite as: Can Urol Assoc J 2017; 11 (1-2):16-23. http://dx.doi.org/10.5489/cuaj.4303

\section{Abstract}

Introduction: Testosterone suppression, or androgen-deprivation therapy (ADT), is an established treatment for recurrent and metastatic prostate cancer (PCa). Based on the accuracy and sensitivity of early assays (c. 1960-1970), the castrate testosterone level was set at $\leq 1.7 \mathrm{nmol} / \mathrm{l}$. Improved sensitivity of testosterone assays shows that both surgical and medical castration can achieve levels $<0.7$ $\mathrm{nmol} / \mathrm{l}$. However, the clinical implications and importance of maximum testosterone suppression remains a subject of controversy. This evidence-based review assesses prospective and retrospective clinical data, linking maximum suppression of testosterone with improved outcomes from ADT.

Methods: PubMed and conference proceedings were searched for studies assessing the impact of low testosterone on clinical outcomes from ADT. The key search terms included combinations of prostate cancer and testosterone, predictive/prognostic, and androgen deprivation. Results were limited to studies investigating the relationship between testosterone levels and clinical outcomes.

Results: Both prospective and retrospective data support a relationship between testosterone levels below the historical standard of $1.7 \mathrm{nmol} / \mathrm{l}$ and improved outcomes. Eight studies showed significant improvements in survival-related outcomes, with the majority of data supporting a testosterone level cutoff of $\leq 0.7 \mathrm{nmol} / \mathrm{l}$.

Conclusions: Tracking both testosterone and prostate-specific antigen (PSA) levels has significant clinical benefits, and the serum testosterone threshold of $\leq 0.7 \mathrm{nmol} / \mathrm{l}$ is a practical goal. The relative levels of testosterone and PSA may indicate continued hormone responsiveness or progression toward castration-resistant prostate cancer (CRPC) and should, therefore, inform treatment strategy. Standardization of assay methods and clinical coordination to facilitate widespread access to state-of the art laboratory equipment is necessary to ensure accurate decision-making.

\section{Introduction}

The extent of prostate cancer (PCa) is often underestimated at the time of diagnosis. The U.S.-based Surveillance, Epidemiology, and End Results (SEER) database indicates that for U.S. men diagnosed with PCa between 1999 and $2006,12 \%$ had regional/locally advanced disease and $4 \%$ had distant metastases. ${ }^{1}$ However, even among men with clinically localized disease treated with radical prostatectomy, approximately $15-40 \%$ will develop prostate-specific antigen (PSA) relapse, ${ }^{2-5}$ suggesting that a proportion of these men had metastases at the time of diagnosis.

The androgen receptor (AR) plays a leading role in the pathogenesis and progression of PCa. ${ }^{6}$ The AR is bound by testosterone and dihydrotestosterone (DHT), resulting in nuclear localization and activation of target gene transcription. ${ }^{7}$ Testosterone suppression as PCa treatment was proposed by Huggins and Hodges in 1941. They observed that orchiectomy or estrogen therapy was an effective treatment for symptomatic metastatic $\mathrm{PCa} .{ }^{8}$ Luteinizing hormone-releasing hormone (LHRH) agonists and antagonists provide medical testosterone suppression, can be reversed, and avoid the negative physical and psychological effects of orchiectomy ${ }^{9-12}$ Androgendeprivation therapy (ADT) by medical or surgical means is the primary first-line treatment for advanced/metastatic $\mathrm{PCa}^{9}$ and most patients respond to this treatment. ${ }^{13,14}$

Early serum testosterone assays, developed in the late 1960s and early 1970s, used double-isotope-derivative dilution with a thin-layer chromatography modification. ${ }^{15}$ This approach was limited in both accuracy and sensitivity. ${ }^{16,17}$ The consequence was that target testosterone suppression levels were defined within the limitations of measurement, as $<1.7 \mathrm{nmol} /$ l. $^{16,18}$ More recent technological advancements include improved radioimmunoassay, as well as chemiluminescent and mass spectrometry methods, ${ }^{19,20}$ which show that both surgical and medical castration can achieve levels 
$<0.7 \mathrm{nmol} / \mathrm{l} .^{16,18}$ Despite these advances in detection accuracy, the clinical relevance of lower testosterone levels remains controversial. This evidence-based review assesses the clinical importance of prospective and retrospective data characterizing the association between testosterone levels during ADT and outcomes in patients with hormone-sensitive, recurrent, and/or metastatic PCa.

\section{Methods}

PubMed (all time to June 16, 2016) and the proceedings of American Society of Clinical Oncology (ASCO; 2014-2016) meetings, the Annual Congress of the European Society for Medical Oncology/European Cancer Congress (ESMO 2014, ESMO/ECCO18, 2015) were searched for studies assessing the impact of low testosterone on clinical outcomes from ADT (Fig. 1). The search string comprised the following key search terms (or respective aliases): prostate cancer AND testosterone AND predictive/prognostic AND androgen deprivation. Results were limited to studies reporting data on the relationship between testosterone levels and clinical outcomes. The literature search was supplemented with a bibliographic review of recently published review articles to confirm inclusion of all relevant studies.

\section{Findings}

Eleven studies, five prospective (Table 1) and six retrospective (Table 2; available at www.cuaj.ca), assessing ADT outcomes relative to level of testosterone achieved on therapy ${ }^{21-31}$ met our eligibility criteria.

\section{Prospective data}

Five prospective, single-cohort studies, with populations ranging in size from 32-626 patients, demonstrated prolonged time to castration-resistant prostate cancer (CRPC) or overall survival (OS), or improved PSA outcomes for PCa patients with serum testosterone levels $\leq 0.7, \leq 0.9, \leq 1.0$, or $\leq 1.1 \mathrm{nmol} / \mathrm{l}$, compared with those who had serum testosterone levels greater than each value, respectively (Table 1). ${ }^{21-23,27,29}$

The largest prospective analysis included data from 626 patients, with localized or locally advanced PCa, either undergoing orchiectomy or receiving LHRH agonist (LHRHA) therapy plus a non-steroidal antiandrogen for a minimum of four weeks. ${ }^{27}$ Serum testosterone levels were assayed every two months and a relationship between testosterone level and time to CRPC was observed. At one year, time to CRPC was significantly improved for patients with nadir testosterone levels $\leq 0.7$ $\mathrm{nmol} / \mathrm{l}$ compared with those with levels between $>0.7 \mathrm{nmol} / \mathrm{l}$ and $<1.7 \mathrm{nmol} / \mathrm{l}$ or $\geq 1.7 \mathrm{nmol} / \mathrm{l}(\mathrm{p}=0.015)$. Median times to CRPC were 10.0, 7.21, and 3.62 years, respectively. Median testosterone level $>0.7 \mathrm{nmol} / \mathrm{l}$ was associated with a higher risk of developing CRPC compared with lower levels $(p=0.02) .{ }^{27}$

In the next largest trial, 206 patients with metastatic PCa received either monthly LHRHA or a three-month depot along with an AR antagonist (bicalutamide or flutamide following bicalutamide withdrawal). ${ }^{29}$ Patients with testosterone levels $\leq 0.9 \mathrm{nmol} / \mathrm{l}$ one month after initiating ADT experienced a longer time to CRPC (mean 19.1 months) compared with those with testosterone levels $>0.9 \mathrm{nmol} / \mathrm{I}$ (mean 14.6 months; $\mathrm{p}=0.0004$ ). Patients with testosterone levels $\leq 0.7 \mathrm{nmol} / \mathrm{l}$ six months after initiating ADT also had a longer time to CRPC (adjusted hazard ratio [HR] 1.99; 95\%

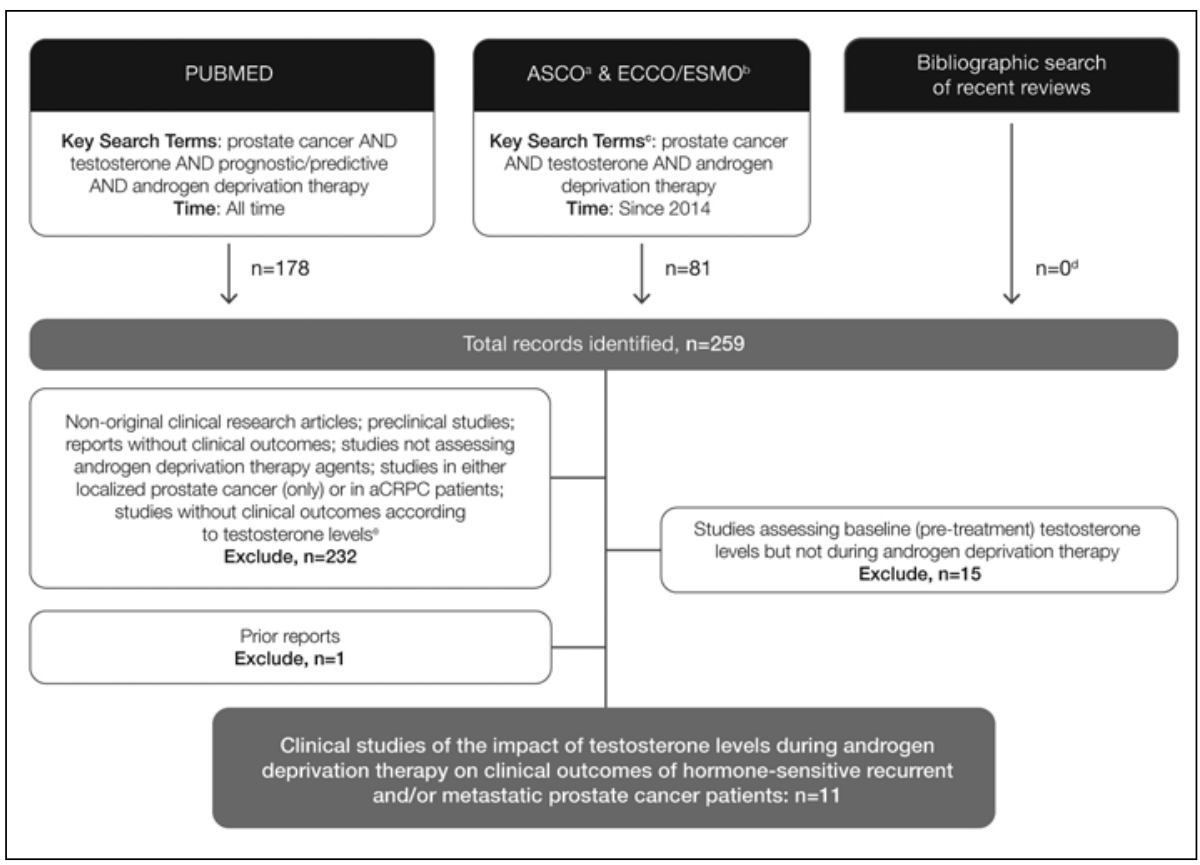

Fig. 1. Preferred reporting items for systematic reviews and meta-analyses diagram for clinical studies of the impact of testosterone levels during ADT on clinical outcomes of hormone-sensitive recurrent and/or metastatic prostate cancer patients. aJCO database; 'ECCO18/ESM02015: EJC database, ESM02014: Annals of Oncology database; ${ }^{\circ}$ or respective aliases; ${ }^{d p r i m a r y}$ reports of eligible studies that were not identified through database search primary reports were defined as the most detailed and current report of the analysis of interest (predictive value of testosterone during ADT); ${ }^{\text {r }}$ rechecked at full text when abstract was not sufficiently clear. aCRPC: advanced castration-resistant prostate cancer; ADT: androgen-deprivation therapy; ASCO: American Society of Clinical Oncology; ECCO: European Cancer Congress; ESMO: European Society of Medical Oncology; EJC: European Journal of Cancer. 
Klotz et al.

\begin{tabular}{|c|c|c|c|c|c|c|}
\hline $\begin{array}{l}\text { Study type } \\
\mathbf{N} \\
\text { Setting }\end{array}$ & ADT regimen(s) & T Level & \begin{tabular}{|c|} 
Time to CRPC \\
(months) \\
HR \\
$(95 \% \mathrm{Cl})$
\end{tabular} & $\begin{array}{c}\text { PFS } \\
\text { (months) } \\
\text { HR } \\
(95 \% \mathrm{Cl})\end{array}$ & $\begin{array}{c}\text { OS } \\
\text { (months) } \\
\text { HR } \\
(95 \% \mathrm{Cl}) \text { or } \\
\text { (range) } \\
\end{array}$ & Other results \\
\hline \multirow{3}{*}{$\begin{array}{l}\text { Klotz } \\
2015^{27} \text { RCT, } \\
\text { Multicentre } \\
626 \\
\text { L \& LA }\end{array}$} & \multirow{3}{*}{$\begin{array}{l}\text { Orchiectomy or LHRH } \\
\text { agonist plus } \\
\text { nonsteroidal } \\
\text { antiandrogen for } \\
\text { minimum of } 4 \mathrm{wks}\end{array}$} & $\begin{array}{c}\leq 0.7 \mathrm{nmol} / \mathrm{l} \\
\text { (NT year } 1 ; \\
\mathrm{n}=489 \text { ) }\end{array}$ & $\begin{array}{l}10.0^{\mathrm{a}}(\mathrm{yrs}) \\
(\mathrm{p}=0.015)^{\mathrm{b}}\end{array}$ & \multirow{3}{*}{ NR } & $\begin{array}{l}\text { Not reached } \\
(\text { CSS; } p=0.02)^{b}\end{array}$ & \multirow{3}{*}{$\begin{array}{l}\text { - Median } T>0.7 \mathrm{nmol} / \mathrm{l} \text { was } \\
\text { associated with higher risk of } \\
\text { developing CRPC ( } \mathrm{p}=0.02 \text { ). } \\
\text { - Maximum } \mathrm{T} \geq 1.7 \mathrm{nmol} / \mathrm{l} \text { was } \\
\text { associated with a significantly } \\
\text { higher rate of progression to } \\
\text { CRPC ( } \mathrm{p}=0.03 \text { ). } \\
\text { - Maximum } T \geq 1.7 \mathrm{nmol} / \mathrm{l} \\
\text { predicted a higher risk of } \\
\text { dying as a result of disease } \\
\text { ( } \mathrm{p}=0.024) \text {. }\end{array}$} \\
\hline & & $\begin{array}{c}>0.7 \text { to }<1.7 \\
\text { nmol/l }(\mathrm{NT} \\
\text { year } 1 ; n=129) \\
\end{array}$ & $\begin{array}{l}7.21^{\mathrm{a}}(\mathrm{yrs}) \\
1.62(1.20- \\
2.18) \\
\end{array}$ & & $\begin{array}{c}10.07^{\mathrm{a}} \text { (yrs) (CSS) } \\
2.08(1.28-3.38)\end{array}$ & \\
\hline & & $\begin{array}{c}\geq 1.7 \mathrm{nmol} / \mathrm{l} \\
\text { (NT year } 1 ; \\
\quad \mathrm{n}=8 \text { ) }\end{array}$ & $\begin{array}{l}3.62^{\mathrm{a}}(\mathrm{yrs}) \\
1.90(0.98- \\
4.70)\end{array}$ & & $\begin{array}{c}\text { Not reached } \\
\text { (CSS) } \\
2.93(0.70-12.30)\end{array}$ & \\
\hline \multirow{2}{*}{$\begin{array}{l}\text { Wang } \\
2016^{29} \\
\text { Single- } \\
\text { centre } \\
206 \\
\text { Met }\end{array}$} & \multirow{2}{*}{$\begin{array}{l}\text { LHRHA every mo or } \\
\text { long-acting LHRHA } \\
\text { every } 3 \text { mos } \\
\text { Bicalutamide } 50 \mathrm{mg} / \\
\text { day } \\
\text { Secondary HT of } \\
\text { LHRHA and flutamide } \\
250 \text { mg } 3 \text { times a day } \\
\text { after bicalutamide } \\
\text { withdrawal for } 6 \text { wks }\end{array}$} & $\begin{array}{c}\leq 0.9 \mathrm{nmol} / \mathrm{l} \\
(\mathrm{n}=98)\end{array}$ & $\begin{array}{c}19.1^{c} \\
(p=0.0004)\end{array}$ & & & \multirow{2}{*}{$\begin{array}{l}\text { - T levels }<1.7 \mathrm{nmol} / \mathrm{l} \text { were not } \\
\text { associated with the effective } \\
\text { time of ADT. } \\
\text { - T levels of } \leq 0.9 \mathrm{nmol} / \mathrm{l} \text { after } \\
\text { the first mo of ADT predicted } \\
\text { longer time to CRPC (adjusted } \\
\mathrm{HR} 1.46 ; 95 \% \mathrm{Cl} 1.08-1.96 ; \\
\mathrm{p}=0.013 \text { ). } \\
\text { - T levels } \leq 0.7 \mathrm{nmol} / \mathrm{l} \text { after } 6 \text { mos } \\
\text { were significantly associated } \\
\text { with a longer time to CRPC } \\
\text { (adjusted HR } 1.99 ; 95 \% \mathrm{Cl} \\
\text { 1.44-2.74; } \mathrm{p}=0.001 \text { ). }\end{array}$} \\
\hline & & $\begin{array}{c}>0.9 \mathrm{nmol} / \mathrm{l} \\
(\mathrm{n}=108)\end{array}$ & $14.6^{c}$ & & & \\
\hline \multirow{3}{*}{$\begin{array}{l}\text { Bertaglia } \\
2013^{21} \\
\text { Single- } \\
\text { centre } \\
153 \\
\text { L, LA \& } \\
\text { Met }\end{array}$} & \multirow{3}{*}{$\begin{array}{l}\text { LHRHAs (long-acting } \\
\text { formulation) every } \\
\quad 3 \text { mos } \\
\text { Bicalutamide } 50 \mathrm{mg} \\
\text { daily during the first } \\
4 \mathrm{wks}\end{array}$} & $\begin{array}{c}<0.7 \mathrm{nmol} / \mathrm{l} \\
(\mathrm{n}=25) \text { vs. } \geq 0.7 \\
\mathrm{nmol} / \mathrm{l}(\mathrm{n}=128)\end{array}$ & \multirow{3}{*}{ NR } & $\begin{array}{c}\text { NR } \\
0.58(0.30-1.15) \\
(T T P ; p=0.12) \\
\end{array}$ & $\begin{array}{c}\text { NR } \\
0.19(0.04-0.76) \\
(p=0.020)^{d}\end{array}$ & \multirow{3}{*}{$\begin{array}{l}\text { The } 56(36.6 \%) \text { patients who } \\
\text { attained ST level of } 1 \mathrm{nmol} / \mathrm{l} \\
\text { or less after } 6 \text { mos of LHRHA } \\
\text { therapy had better survival } \\
\text { than the } 97 \text { patients }(63.4 \%) \\
\text { who did not (HR } 0.45 ; 95 \% \mathrm{Cl} \\
0.22-0.94 ; p=0.034) \text {. }\end{array}$} \\
\hline & & $\begin{array}{c}\leq 1.0 \mathrm{nmol} / \mathrm{l} \\
(\mathrm{n}=56) \text { vs. }>1.0 \\
\mathrm{nmol} / \mathrm{l}(\mathrm{n}=97)\end{array}$ & & $\begin{array}{c}\text { NR } \\
0.76(0.46-1.26) \\
(T T P ; p=0.30)\end{array}$ & $\begin{array}{c}\text { NR } \\
0.45(0.22-0.94) \\
(p=0.034)\end{array}$ & \\
\hline & & $\begin{array}{c}<1.7 \mathrm{nmol} / \mathrm{l} \\
(\mathrm{n}=94) \text { vs. } \geq 1.7 \\
\mathrm{nmol} / \mathrm{l}(\mathrm{n}=59)\end{array}$ & & $\begin{array}{c}\text { NR } \\
0.84(0.52-1.37) \\
(T T P ; p=0.51)\end{array}$ & $\begin{array}{c}\text { NR } \\
0.74(0.42-1.33) \\
(p=0.32) \\
\end{array}$ & \\
\hline $\begin{array}{l}\text { Kawakami } \\
2013^{23} \\
\text { Single- } \\
\text { centre } \\
69 \\
\text { Met }\end{array}$ & $\begin{array}{l}\text { LHRH agonist } \\
\text { (goserelin, leuprolide } \\
\text { or buserelin) }\end{array}$ & $\begin{array}{c}>0.7 \mathrm{nmol} / \mathrm{l} \\
(\mathrm{n}=13)\end{array}$ & NR & \multicolumn{3}{|c|}{$\begin{array}{l}\text { Other results: } \\
\text { - PSA minimum, maximum, median, and mean were all higher for } \\
\text { the cohort of patients with levels of } \mathrm{T}>0.7 \mathrm{nmol} / \mathrm{l} \text {. } \\
\text { - PSA correlated with total T (correlation } 0.42 ; \mathrm{p}=0.003) \text {. } \\
\text { - T levels }>0.7 \mathrm{nmol} / \mathrm{l} \text { were found in } 17 \%(7 / 41), 19 \%(4 / 21) \text {, and } 28 \% \\
\text { (2/7) of patients on goserelin, leuprolide, and buserelin, respectively. } \\
\text { - No statistical difference among the } 3 \mathrm{LHRH} \text { agonists in proportion } \\
\text { of patients not achieving optimal levels of T. }\end{array}$} \\
\hline $\begin{array}{l}\text { Dason } \\
2013^{22} \\
\text { Cohort } \\
\text { series } \\
32 \\
\text { L, LA \& } \\
\text { Met }\end{array}$ & $\begin{array}{c}\text { LHRH agonist } \\
\text { (goserelin, leuprolide } \\
\text { or triptorelin), } \\
\text { 3-mo depots and } \\
\text { a 1-mo course of } \\
\text { bicalutamide on ADT } \\
\text { initiation } \\
\text { OR } \\
\text { LHRH antagonist } \\
\text { (degarelix), 1-mo } \\
\text { depots }\end{array}$ & $\begin{array}{l}\text { 1.1-1.7 } \mathrm{nmol} / /^{\mathrm{c}} \\
(1 \mathrm{yr} ; \mathrm{n}=4)\end{array}$ & $\begin{array}{c}33.1^{a} \\
(p=0.05)\end{array}$ & \multicolumn{3}{|c|}{$\begin{array}{l}\text { Other results: } \\
\text { - Patients with a 9-mo absolute } T \text { measurement }<1.1 \mathrm{nmol} / / \mathrm{had} \\
\text { increased time to } \mathrm{CRPC}(\mathrm{p}=0.001 \text {, median: } 33.1 \mathrm{mos}[<1.1 \mathrm{nmol} / \mathrm{l}] \text { vs. } \\
12.5 \mathrm{mos}[>1.1 \mathrm{nmol} / \mathrm{l}]) \text {. } \\
\text { - Patients with a } 6 \text {-mo absolute } \mathrm{T}<1.1 \mathrm{nmol} / \mathrm{l} \text { had an increased time } \\
\text { to } \mathrm{CRPC} \text {, which was not statistically significant }(\mathrm{p}=0.085 \text {, median: } \\
33.1 \mathrm{months}[<1.1 \mathrm{nmol} / \mathrm{l}] \text { vs. } 14.6 \text { mos }[>1.1 \mathrm{nmol} / \mathrm{l}]) \text {. } \\
\text { - Mean T level }<0.7 \mathrm{nmol} / \mathrm{l} \text { compared to } 0.7-1.7 \mathrm{nmol} / \mathrm{l} \text { at } 6,9 \text {, or } 12 \\
\text { mos did not significantly predict time to } \mathrm{CRPC} \text {. }\end{array}$} \\
\hline
\end{tabular}

aMedian; ${ }^{b}$ adjusted for multiple test based on the Hochberg method (Hochberg et al. Biometrics 1988;75:800-2); ${ }^{\circ}$ mean; ${ }^{\mathrm{d}}$ serum T level $<0.7 \mathrm{nmol} / \mathrm{l}$ is significantly associated with lower risk of death. ADT: androgen-deprivation therapy; Cl: confidence interval; CRPC: castration-resistant prostate cancer; CSS: cause (cancer)-specific survival; HR: hazard ratio; HT: hormonal therapy; L: localized; LA: locally advanced; LHRH(A): luteinizing hormone-releasing hormone (agonist); Met: metastatic; mo(s): month(s); N or n: number of patients; NR: not reported; NT: nadir

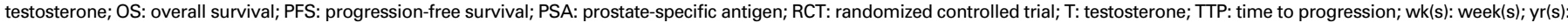
year(s). 
confidence interval [Cl] 1.44-2.74; $\mathrm{p}=0.001$ ) compared with those with testosterone levels of $>0.7 \mathrm{nmol} / \mathrm{l} .{ }^{29}$

Another trial enrolled 153 patients with localized, locally advanced, or metastatic PCa. ${ }^{21}$ Treatment included LHRHA every three months plus daily bicalutamide during the first four weeks, with testosterone levels assessed between six and seven months. A relationship was observed between lower testosterone levels and OS, but not time to progression (TTP). Patients with serum testosterone levels of $<0.7$ $\mathrm{nmol} / \mathrm{l}$ and $\leq 1.0 \mathrm{nmol} / \mathrm{l}$ demonstrated improved OS compared to those with testosterone $\geq 0.7 \mathrm{nmol} / \mathrm{l}$ (HR 0.19; $95 \%$ $\mathrm{Cl} 0.04-0.76 ; \mathrm{p}=0.020)$ and testosterone $>1.0 \mathrm{nmol} / \mathrm{l}(\mathrm{HR}$ $0.45 ; 95 \% \mathrm{Cl} 0.22-0.94 ; \mathrm{p}=0.034)$, respectively. When comparing data from patients achieving testosterone levels $<1.7 \mathrm{nmol} / \mathrm{l}$ to those with testosterone $\geq 1.7 \mathrm{nmol} / \mathrm{l}$, no significant difference in OS was observed (HR $0.74 ; 95 \% \mathrm{Cl}$ $0.42-1.33 ; \mathrm{p}=0.32) .{ }^{21}$ Together, these data suggest that a lower testosterone suppression level cutoff, at or below 1.0 $\mathrm{nmol} / \mathrm{l}$, may predict greater OS benefit from ADT, while no predictive capacity is apparent with the higher cutoff of $<1.7$ nmol/l. TTP was not significantly different between patients with serum testosterone levels of $<0.7 \mathrm{nmol} / \mathrm{l}, \leq 1.0 \mathrm{nmol} / \mathrm{l}$, or $<1.7 \mathrm{nmol} / \mathrm{l}$ compared with those with testosterone $\geq 0.7$ $\mathrm{nmol} / \mathrm{l}(\mathrm{HR} 0.58 ; 95 \% \mathrm{Cl} 0.30-1.15 ; \mathrm{p}=0.12),>1 \mathrm{nmol} / \mathrm{l}(\mathrm{HR}$ $0.76 ; 95 \% \mathrm{Cl} 0.46-1.26 ; \mathrm{p}=0.30)$, or $\geq 1.7 \mathrm{nmol} / \mathrm{l}$ (HR 0.84; $95 \% \mathrm{Cl} 0.52-1.37 ; p=0.51$ ), respectively.

Improved PSA outcomes and time to CRPC were associated with low testosterone levels in two additional studies. The first trial enrolled 69 patients with metastatic PCa to receive an LHRHA. ${ }^{23}$ At $\geq 3$ months, higher PSA levels were observed in patients with serum testosterone levels of $>0.7 \mathrm{nmol} / \mathrm{l} \mathrm{com}-$ pared to those with levels $\leq 0.7 \mathrm{nmol} / .{ }^{23}$ The smallest prospective trial enrolled 32 patients with localized, locally advanced, or metastatic PCa treated with either an LHRHA (three-month depot) plus bicalutamide (one-month course upon ADT initiation) or one-month depot of the LHRH antagonist degarelix. ${ }^{22}$ Patients with testosterone levels of $<1.1 \mathrm{nmol} / \mathrm{l}$ at one year demonstrated longer time to CRPC compared to those with testosterone levels between 1.1 and $1.7 \mathrm{nmol} / \mathrm{l}$ (median 33.1 vs. 12.5 months, respectively; $\mathrm{p}=0.05){ }^{22}$

\section{Retrospective data}

Four of six retrospective studies of localized, locally advanced, or metastatic PCa ranging in size from 73-2196 patients also demonstrated improved outcomes (lower rates of testosterone breakthrough, time to CRPC, progression-free survival [PFS], cause specific survival [CSS], or OS) for patients achieving suppression $\leq 0.7 \mathrm{nmol} / \mathrm{l}$ or $\leq 1.1 \mathrm{nmol} / \mathrm{l}$, compared to those with serum testosterone level $>0.7 \mathrm{nmol} / \mathrm{l}$ or $>1.1 \mathrm{nmol} / \mathrm{l}$, respectively (Table 2; available at www.cuaj.ca). ${ }^{26,28,30,31}$

The largest study $(n=2196)$ analyzed testosterone breakthrough data for patients receiving adjuvant LHRHA therapy following curative radiotherapy. ${ }^{31}$ Lower rates of testosterone breakthrough (increase in serum testosterone $>0.7 \mathrm{nmol} / \mathrm{I}$ during ADT) were associated with improved PSA kinetics, an indicator of disease control. Data showed breakthrough rates with testosterone level increase to $>1.1 \mathrm{nmol} / \mathrm{l}$ of $6.6 \%$ per patient-course and 5.4\% per LHRHA injection, while breakthrough rates with testosterone level increase to $>1.7 \mathrm{nmol} / \mathrm{I}$ of $3.4 \%$ per patient-course and $2.2 \%$ per LHRHA injection. Younger men were more likely to experience testosterone breakthrough $(p<0.001)$ and $16 \%$ of patients experienced repeated breakthroughs. PSA kinetics and post-treatment PSA nadir were lower for those without breakthrough $(0.02$ $\mathrm{ng} / \mathrm{ml}$ ) compared with those with testosterone breakthrough $(0.04 \mathrm{ng} / \mathrm{ml} ; \mathrm{p}=0.008$ and $\mathrm{p}=0.003$ for testosterone breakthrough level $>1.1 \mathrm{nmol} / \mathrm{l}$ or $>1.7 \mathrm{nmol} / \mathrm{l}$, respectively). ${ }^{31}$

A multicentre study analyzed data from 225 patients receiving complete androgen blockade with an LHRH agonist or antagonist, or surgical castration plus antiandrogens for localized, locally advanced, or metastatic PCa. ${ }^{26}$ The data demonstrated improved outcomes for patients with testosterone levels $<0.7 \mathrm{nmol} / \mathrm{l}$ compared with those with testosterone $\geq 0.7 \mathrm{nmol} / \mathrm{l}$. Median PFS was 16.3 vs. 11.0 months $(p=0.1163)$, while median OS was 68.3 vs. 28.3 months $(p<0.0014)$, respectively. ${ }^{26}$ Additional univariate analyses showed that significantly improved OS outcomes were limited to low testosterone levels of $<0.6 \mathrm{nmol} / \mathrm{l}(\mathrm{p}=0.0190)$, $<0.7 \mathrm{nmol} / \mathrm{l}(\mathrm{p}=0.0020)$, and $<1.1 \mathrm{nmol} / \mathrm{l}(\mathrm{p}=0.0146)$, but not associated with very low testosterone levels $<0.3 \mathrm{nmol} / \mathrm{l}$ and $<0.4 \mathrm{nmol} / \mathrm{l}$.

The largest single-centre study analyzed data from 129 metastatic PCa patients treated with goserelin and measured serum testosterone levels every three months. ${ }^{28}$ The study showed that higher six-month testosterone levels were associated with an increased risk of death (HR 1.333; $95 \% \mathrm{CI}$ $1.053-1.687 ; p<0.05) .^{28}$

An additional single-centre analysis included data from 96 locally advanced or metastatic PCa patients treated with surgical castration or ADT via LHRHA therapy and/or an antiandrogen, and reported an association between low testosterone level and improved OS and prognosis, but not PFS. ${ }^{24}$ The study compared outcomes among patients with testosterone level of $0.1 \mathrm{nmol} / \mathrm{l}$ with those showing levels between 0.1 and $2.6 \mathrm{nmol} / \mathrm{l}$ and demonstrated no difference in PFS $(p=0.70)$, while OS was improved for patients with lower testosterone levels $(p=0.014) .{ }^{24}$ Analysis of survival rate from the point of progression also showed improved prognosis for the group with testosterone levels of $0.1 \mathrm{nmol} / \mathrm{l}$ compared with those with testosterone levels between 0.1 and $2.6 \mathrm{nmol} / \mathrm{l}(\mathrm{p}=0.0044)$.

A single-centre analysis of testosterone breakthrough, defined as an increase in serum testosterone $>0.7 \mathrm{nmol} / \mathrm{l}$ during ADT, included data from 73 localized or locally advanced PCa patients treated with LHRHA as a three-month 
Klotz et al.

depot with or without daily bicalutamide. ${ }^{30}$ A relationship between low testosterone level and improved PFS was observed. Testosterone levels were assayed three times over six months and PFS outcomes, relative to testosterone level increases during treatment, were compared. Patients with all three testosterone measurements $<0.7 \mathrm{nmol} / \mathrm{l}$ had the longest mean survival free of androgen-independent progression (mean 106 months) compared to those with any testosterone level increase between 0.7 and1.7 nmol/l (mean 90 months) or $>1.7 \mathrm{nmol} / \mathrm{l}$ (mean 72 months). Additional analyses indicated that the lowest serum testosterone threshold with clinical impact was $1.1 \mathrm{nmol} / \mathrm{l}(\mathrm{p}=0.0258)$, as patients with all three testosterone assays $<1.1 \mathrm{nmol} / \mathrm{l}$ had a mean survival free of androgen-independent progression of 137 months vs. 88 months for those with any breakthrough increase $>1.1$ $\mathrm{nmol} / \mathrm{l}(\mathrm{p}<0.03) .{ }^{30}$ When considering ADT modality, a benefit of combined androgen blockade (LHRH plus bicalutamide) compared to $\mathrm{LHRH}$ alone was observed among men with poorly suppressed testosterone and those with breakthrough increases $>1.7 \mathrm{nmol} / \mathrm{l}(\mathrm{p}=0.0249)$, but in not those with breakthrough increases $>1.1 \mathrm{nmol} / \mathrm{l}(\mathrm{p}=0.3350)$ or those with no increases above the $1.1 \mathrm{nmol} / \mathrm{l}$ threshold $(\mathrm{p}=0.2801){ }^{30}$

Finally, an analysis of data from 69 metastatic PCa patients treated with LHRHA plus bicalutamide, with testosterone levels assayed every 3-6 months, demonstrated no relationship between testosterone level and PSA outcomes, TTP, CSS, or OS. ${ }^{25}$ No difference between time to PSA progression $(p=0.66)$, OS $(p=0.17)$, or CSS $(p=0.29)$ was found when comparing testosterone levels $<0.7 \mathrm{nmol} / \mathrm{l}$ with those $\geq 0.7$ $\mathrm{nmol} / \mathrm{l} .{ }^{25}$ Results also indicated that no median testosterone level threshold assessed $(0.5,0.7$, or $1.1 \mathrm{nmol} / \mathrm{l})$ showed a significant association with survival-related outcomes.

\section{Discussion}

\section{Are testosterone levels below the historical standard for castrate level associated with improved outcomes?}

Both prospective and retrospective data support a relationship between testosterone levels below $1.7 \mathrm{nmol} / \mathrm{l}$ - the historical standard for castrate level - and improved outcomes. Five prospective trials demonstrated that patients achieving serum testosterone levels $\leq 0.7, \leq 0.9, \leq 1.0$, or $\leq 1.1 \mathrm{nmol} / \mathrm{l}$, were associated with longer time to CRPC and/or death compared with those having higher testosterone levels, respectively. ${ }^{21-23,27,29}$ Four of six retrospective studies of localized, locally advanced, or metastatic PCa also demonstrated improved outcomes (lower rates of testosterone breakthrough, PFS, CSS, or OS) for patients achieving testosterone suppression $\leq 0.7 \mathrm{nmol} / /$ or $\leq 1.1 \mathrm{nmol} / \mathrm{I}$ compared to those with serum testosterone levels $>0.7 \mathrm{nmol} / \mathrm{l}$ or $>1.1 \mathrm{nmol} / \mathrm{l}$, respectively. ${ }^{26,28,30,31} \mathrm{~A}$ similar trend was seen in a recent post-hoc analysis of the ICELAND study, which demonstrated an association between lower nadir testosterone level and a trend toward longer time to PSA (CRPC) progression $(\leq 0.7$ $\mathrm{nmol} / \mathrm{l}$ vs. $>0.7 \mathrm{nmol} / \mathrm{l}$ to $\leq 1.7 \mathrm{nmol} / \mathrm{l} ; \mathrm{HR} 5.06 ; 95 \% \mathrm{Cl} 1.3-$ $16.1 ; p=0.062$; at the time of publication, the ICELAND study report was only available in abstract form) ${ }^{32}$ Overall, these data provide compelling support for a relationship between low testosterone levels and improved outcomes. There are, however, significant limitations, including variations in methodology across studies (testosterone assay timing, specific assays used, and associated detection limits). While available analyses indicate an association between testosterone level and outcome, there are limited data that predict whether adjusting therapy
Fig. 2. Management strategies using testosterone suppression data for recurrent and/or metastatic prostate cancer. a Non-metastatic CRPC; bfollow CUA-CUOG guidelines for management of CRPC (Saad F, et al. Can Urol Assoc J 2015;9:90-6). ADT: androgen-deprivation therapy; CRPC: castrationresistant prostate cancer; PSA, prostate-specific antigen.

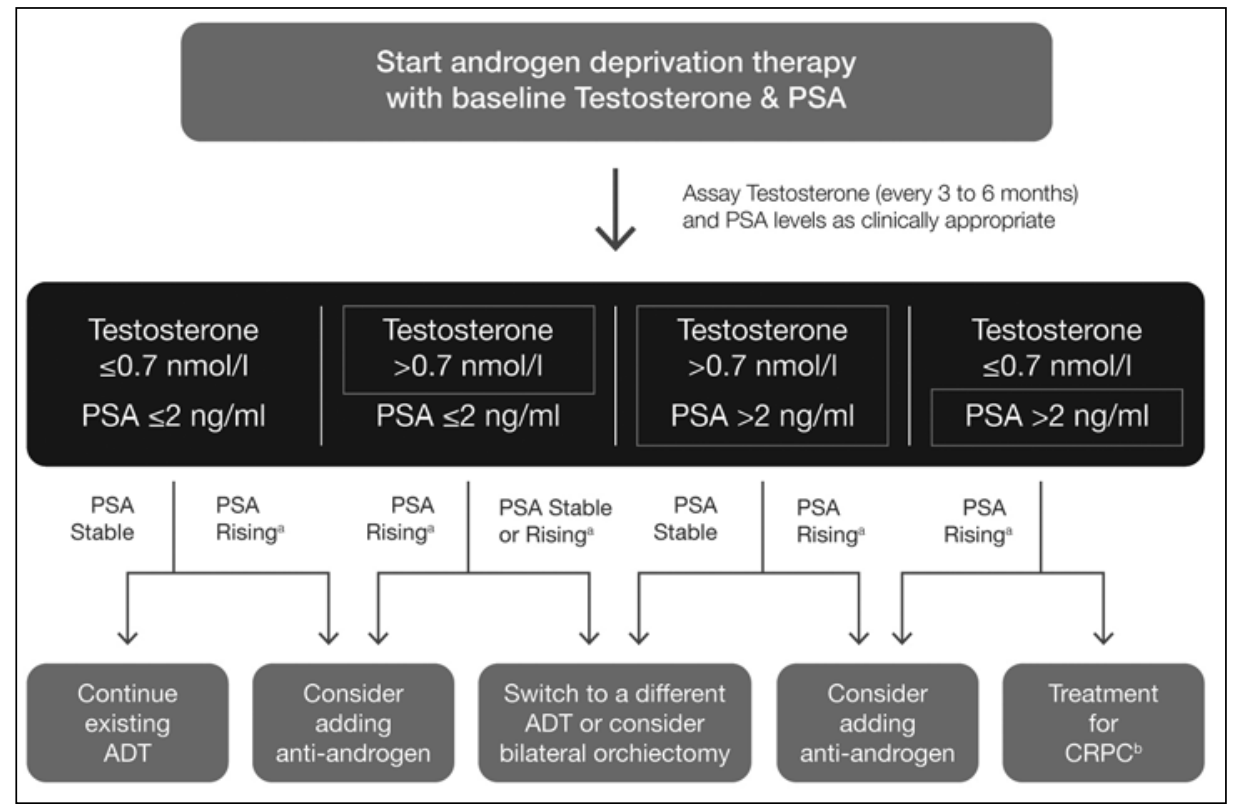


to achieve a lower level of testosterone will result in improved outcomes. Additional prospective studies are necessary to confirm and further clarify findings.

\section{What testosterone threshold should be used clinically to guide treatment?}

Among the 11 trials reviewed, nine reported survival-related outcomes for patients with testosterone levels ranging from $\leq 0.1 \mathrm{nmol} / \mathrm{l}$ to $<1.1$ $\mathrm{nmol} / \mathrm{l},{ }^{21,22,24,26-30}$ eight of which showed significant improvements in these outcomes. A single retrospective study observed a significant improvement in OS with testosterone levels of $\leq 0.1 \mathrm{nmol} / \mathrm{l} \mathrm{com-}$ pared with levels $>0.1 \mathrm{nmol} / \mathrm{l} ; \mathrm{p}=0.014)^{24}$ and two studies, one prospective ${ }^{22}$ and one retrospective, ${ }^{30}$ showed significant improvements in PFS-related outcomes (time to CRPC, $\mathrm{p}=0.05$ and survival free of androgen-independent progression, $\mathrm{p}<0.03$, respectively) at testosterone levels $<1.1 \mathrm{nmol} / \mathrm{l}$ compared with $>1.1 \mathrm{nmol} / \mathrm{l}$. However, the majority of studies assessing survival-related outcomes used a testosterone level cutoff of $\leq 0.7 \mathrm{nmol} / \mathrm{l} .{ }^{21,25-27,30}$ Four trials assessed OS and/or CSS-related outcomes associated with testosterone levels $\leq 0.7 \mathrm{nmol} / \mathrm{l},{ }^{21,25-27}$ with three demonstrating significantly improved outcomes compared to those associated with higher testosterone levels (OS, $p=0.020$ and $p=0.0014$, respectively and CSS; $p=0.02) .^{21,26,27}$ An additional trial demonstrated a significantly lower risk of death with mean six-month testosterone level of $1.4 \mathrm{nmol} / \mathrm{l} \mathrm{vs}$. higher levels $(p<0.05),{ }^{28}$ while two prospective trials each demonstrated improvements in time to CRPC with testosterone levels $\leq 0.9$ and $\leq 0.7 \mathrm{nmol} / \mathrm{l}$ compared with higher levels $\left(p=0.0004\right.$ and $p=0.015$, respectively). ${ }^{27,29}$ Finally, a retrospective analysis showed no OS or CSS benefits for testosterone level $<0.7 \mathrm{nmol} / \mathrm{l}$ compared with $\geq 0.7 \mathrm{nmol} / \mathrm{l}$ $\left(p=0.17\right.$ and $p=0.29$, respectively).$^{25}$ Although prospective studies are necessary to assess whether adjusting therapy to achieve a lower level of testosterone will result in improved outcomes, observational studies suggest that lowering the target threshold of testosterone to $\leq 0.7 \mathrm{nmol} / \mathrm{l}$ was most closely associated with improved survival-related outcomes and a prudent goal for therapy (Fig. 2). While awaiting prospective validation of these findings and standardization of laboratory procedures for assessment of lower testosterone levels, clinicians should take advantage of clinical networks, coordination of care, and central clinical laboratories to ensure the capacity for testosterone measurement at or below the $0.7 \mathrm{nmol} / \mathrm{l}$ threshold.

Stem cells

Partially androgen insensitive

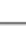
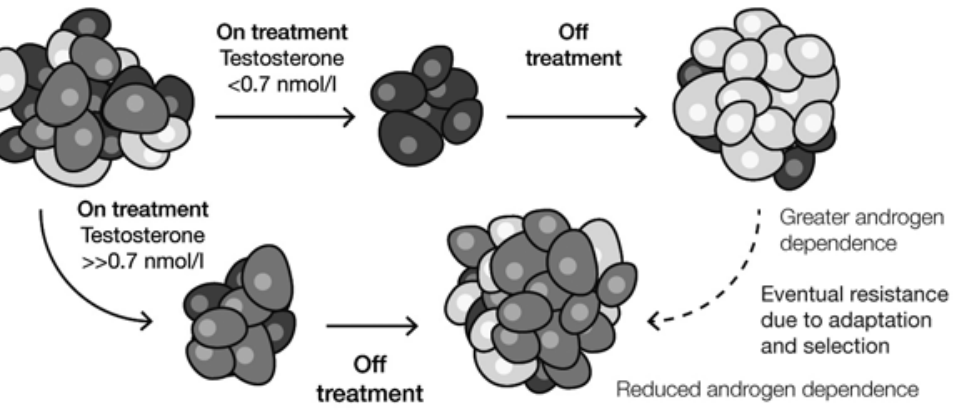

treatment

Reduced androgen dependence

ig. 3. Three-cell-type model demonstrating importance of low testosterone in intermittent androgen-deprivation therapy. Adapted from Klotz L, Toren P. Androgen deprivation erapy in advanced prostate cancer: Is intermittent therapy the new standard of care? urr Oncol 2012;19:S13-21. Copyright 2012 by Multimed Inc. Adapted with permission.

\section{What impact do changing testosterone and PSA levels have on disease management?}

Patients undergoing ADT should be monitored regularly for testosterone (every 3-6 months) and PSA levels as clinically appropriate throughout the first year of treatment (Fig. 2) ${ }^{27} \mathrm{~A}$ baseline testosterone level assay followed by assessments immediately before each LHRHA dose is appropriate timing to ensure testosterone suppression is achieved and sustained throughout the dosing interval. A testosterone level above the target threshold of $0.7 \mathrm{nmol} / \mathrm{l}$ for any measurement taken during continuous ADT or the on-therapy intervals of intermittent ADT within the first year may indicate treatment failure and should prompt consideration of an alternate medical or surgical therapy (e.g., switch from LHRHA to a different agonist or an LHRA antagonist or vice versa; add an antiandrogen; or consider bilateral orchiectomy; Fig. 2). ${ }^{27}$ Rising PSA with adequate testosterone suppression indicates progression towards CRPC and warrants treatment in line with the Canadian Urological Association-Canadian Urological Oncology Group (CUA-CUOG) guidelines for the management of CRPC. ${ }^{33}$

The efficacy of LHRH agonist to antagonist switch as a treatment option for patients with rising testosterone levels was assessed in a recent prospective study that enrolled eight patients with CRPC and testosterone level $\geq 0.7 \mathrm{nmol} / \mathrm{l}$ during prior ADT. ${ }^{34}$ The response rate was $25.0 \%$, and the proportion of cases with PSA decline was $62.5 \%$. One patient had a complete response, with PSA level of $0.02 \mathrm{ng} / \mathrm{ml}$, which was maintained for 12 months. In five out of eight cases $(62.5 \%)$, serum testosterone levels dropped to $<0.7 \mathrm{nmol} / \mathrm{l}$. Overall, findings suggested that switching from LHRH agonist to antagonist may be a suitable treatment option for patients with testosterone levels $\geq 0.7 \mathrm{nmol} / \mathrm{l} .{ }^{34}$ 
Klotz et al.

Intermittent ADT, with its associated benefits in quality of life, has become a common treatment option. Tracking testosterone and PSA levels both on and off therapy provides important data to guide ongoing treatment. Rising PSA levels after testosterone recovery during the off-treatment interval occurs normally, and should result in re-initiating therapy, usually when the PSA reaches a level of 10-20 ng/ml. Rising PSA with adequately suppressed testosterone may indicate progression toward CRPC, even if the patient is not receiving LHRH agonist/antagonist treatment.

A conundrum in this field is the non-inferiority of intermittent therapy, where the testosterone rises during the offtreatment interval, in light of the importance of achieving low testosterone during ADT. In fact, these observations can be reconciled. The concept is that aggressive therapy, which lowers testosterone below $0.7 \mathrm{nmol} / \mathrm{l}$, results in more complete cell kill during the treatment period, repopulation with clones of androgen-sensitive cells during the off-treatment interval (Fig. 3), and response to the next cycle of ADT. ${ }^{35}$ The fact that low levels of testosterone are beneficial during ADT treatment does not imply that these low levels must be continuously sustained to achieve the benefit.

\section{Conclusions and future directions}

Prospective and retrospective data provide compelling support for an association between testosterone levels of $\leq 0.7$ and greater benefit from ADT compared to outcomes associated with higher levels. This testosterone threshold reflects advances in assay technology and is well below the historical castrate testosterone level of $1.7 \mathrm{nmol} / \mathrm{l}$ established decades ago. Tracking both testosterone and PSA levels has significant clinical implication throughout continuous ADT, as well as both on and off therapy during intermittent ADT. The relative levels of testosterone and PSA may indicate continued hormone responsiveness or progression toward CRPC, and should inform treatment accordingly.

Further prospective validation of a lower testosterone threshold and associated ADT benefit is needed to confirm and clarify findings, as well as determine the threshold associated with the greatest clinically significant therapeutic benefit. In the meantime, the serum testosterone threshold of $\leq 0.7 \mathrm{nmol} / \mathrm{l}$ is a practical goal, as this level has been associated with improved ADT outcomes in both prospective and retrospective analyses and is consistently detectable via new technology. Finally, standardization of assay methods and clinical coordination to ensure widespread access to stateof-the-art laboratory equipment will be necessary to ensure clinical applicability.

Competing interests: Dr. Klotz has received honoraria and research funding from AbbVie, Amgen, Astellas, Aventis, Ferring, and Janssen. Dr. Collins has received compensation as a medical writer for Kaleidoscope Strategic. Dr. Gleave has been an advisor for Astellas, AstraZeneca, Bayer, and
Janssen; has received payment as a consultant for Astellas, Bayer, Janssen, and OncoGenex; and is a cofounder and shareholder in OncoGenex, for which he also holds patents for OGX-011 and OGX-427. Dr. Pickles has been and advisor for AbbVie, Astellas, and Janssen; and has received honoraria from AbbVie, AstraZeneca, Bayer, and Ferring. Dr. Pouliot has been an advisor for Amgen, Astellas, and Pfizer; a speaker for Sanofi; has received payment from Amgen, Astellas, AstraZeneca, Janssen, and Sanofi; and has received honoraria from Amgen, Astellas, AstraZeneca, Janssen, Pfizer, and Sanofi. Dr. Saad has been an advisor for and has received honoraria and/or research funding from Abbvie, Sanofi, and Takeda. Dr. Breau reports no competing personal or financial interests.

Authors of this review received data collection and administrative and writing support from Kaleidoscope Strategic, an independent oncology publications firm. Support for these services was provided in an unrestricted fashion from Sanofi Canada. The opinions presented in the paper represent those of the authors and not of the sponsor; none of the clinical authors were paid for writing this review. The medical writer is named as an author according to ICMJE criteria and disclosures have been provided. The sponsor did not contribute to the design or development of the article and did not see the drafts or the final manuscript prior to submission. No grant numbers apply.

Acknowledgements: The authors thank Deanna McLeod and llidio Martins of Kaleidoscope Strategic for research, editorial, and administrative assistance in preparing the review, and Sanofi Canada for providing funding.

This paper has been peer-reviewed.

\section{References}

1. Brawley OW. Prostate cancer epidemiology in the United States. World I Urol 2012;30:195-200. https://doi.org/10.1007/s00345-012-0824-2

2. Han $M$, Partin AW, Zahurak $M$, et al. Biochemical (prostate specific antigen) recurrence probability following radical prostatectomy for clinically localized prostate cancer. J Urol 2003;169:517-23. https://doi.org/10.1016/S0022-5347(05)63946-8

3. Pound CR, Partin AW, Eisenberger MA, et al. Natural history of progression after PSA elevation following radical prostatectomy. JAMA 1999;281:1591-7. https://doi.org/10.1001/jama.281.17.1591

4. Han M, Partin AW, Piantadosi S, et al. Era-specific biochemical recurrence-free survival following radical prostatectomy for clinically localized prostate cancer. J Urol 2001;166:416-9. https://doi.org/10.1016/ S0022-5347(05)65955-1

5. Han M, Partin AW, Pound CR, et al. Long-term biochemical disease-free and cancer-specific survival following anatomic radical retropubic prostatectomy. The 15-year Johns Hopkins experience. Urol Clin North Am 2001;28:555-65. https://doi.org/10.1016/50094-0143(05)70163-4

6. Rodrigues $\mathrm{DN}$, Boysen $\mathrm{G}$, Sumanasuriya $\mathrm{S}$, et al. The molecular underpinnings of prostate cancer: impacts on management and pathology practice. J Pathol 2016;Epub 2016 0ct 18. https://doi.org/10.1002/ path. 4826

7. Lu NZ, Wardell SE, Burnstein KL, et al. International Union of Pharmacology. LXV. The pharmacology and classification of the nuclear receptor superfamily: Glucocorticoid, mineralocorticoid, progesterone, and androgen receptors. Pharmacol Rev 2006;58:782-97. https://doi.org/10.1124/pr.58.4.9

8. Huggins C, Hodges CV. Studies on prostatic cancer. I. The effect of castration, of estrogen, and androgen injection on serum phosphatases in metastatic carcinoma of the prostate. Cancer Res 1941;1:293-7.

9. Cornford P, Bellmunt J, Bolla M, et al. EAU-ESTRO-SIOG guidelines on prostate cancer. Part II: Treatment of relapsing, metastatic, and castration-resistant prostate cancer. Eur Urol 2016;Epub 2016 Aug 31. https://doi.org/10.1016/i.eururo.2016.08.002

10. Seidenfeld J, Samson DJ, Hasselblad V, et al. Single-therapy androgen suppression in men with advanced prostate cancer: A systematic review and meta-analysis. Ann Intern Med 2000;132:566-77. https://doi.org/10.7326/0003-4819-132-7-200004040-00009

11. Crawford ED, Shore ND, Moul JW, et al. Long-term tolerability and efficacy of degarelix: 5-year results from a phase 3 extension trial with a one-arm crossover from leuprolide to degarelix. Urol 2014;83:1122-8. https://doi.org/10.1016/j.urology.2014.01.013 
12. Van Poppel H, Klotz L. Gonadotropin-releasing hormone: An update review of the antagonists vs. agonists. Int J Urol 2012;19:594-601.htrps://doi.org/10.1111/i.1442-2042.2012.02997.x

13. Hoimes CJ, Kelly WK. Redefining hormone resistance in prostate cancer. Ther Adv Med Oncol 2010;2:10723. https://doi.org/10.1177/1758834009356433

14. Hou X, Flaig TW. Redefining hormone sensitive disease in advanced prostate cancer. Adv Urol 2012;2012:978531. https://doi.org/10.1155/2012/978531

15. Burger HG, Kent JR, Kellie AE. Determination of testosterone in human peripheral and adrenal vs plasma. J Clin Endocrinol Metab 1964;24:432-41. https://doi.org/10.1210/icem-24-5-432

16. Oefelein MG, Feng A, Scolieri MJ, et al. Reassessment of the definition of castrate levels of testosterone: implications for clinical decision-making. Urol 2000;56:1021-4. https://doi.org/10.1016/S00904295(00)00793-7

17. Wikke TJ, Utley DJ. Total testosterone, free-androgen index, calculated free testosterone, and free testosterone by analog RIA compared in hirsute women and in otherwise-normal women with altered binding of sex-hormone-binding globulin. Clin Chem 1987;33:1372-5.

18. Nishiyama T. Serum testosterone levels after medical or surgical androgen deprivation: A comprehensive review of the literature. Urol Oncol 2014;32:38.e17-28. https://doi.org/10.1016/i. urolonc.2013.03.007

19. Wheeler MJ, D'Souza A, Matadeen J, et al. Ciba Corning ACS: 180 testosterone assays evaluated. Clin Chem 1996;42:1445-9.

20. Field HP, Wheeler MJ. The measurement of androgens. Methods Mol Biol 2013;1065:211-26. https://doi.org/10.1007/978-1-62703-616-0_13

21. Bertaglia V, Tucci $M$, Fiori $C$ et al. Effects of serum testosterone levels after 6 months of androgen deprivation therapy on the outcome of patients with prostate cancer. Clin Genitourin Cancer 2013;11:325-30. https://doi.org/10.1016/i.llgc.2013.01.002

22. Dason $S$, Allard CB, Tong J, et al. Defining a new testosterone threshold for medical castration: Results from a prospective cohort series. Can Urol Assoc J 2013;7:E263-7. hitps://doi.org/10.5489/cuaj.471

23. Kawakami J, Morales A. Clinical significance of suboptimal hormonal levels in men with prostate cancer treated with LHRH agonists. Can Urol Assoc J 2013;7:E226-30. https://doi.org/10.5489/cuai.540

24. Shiota $M$, Fujimoto $\mathrm{N}$, Yokomizo $\mathrm{A}$, et al. The prognostic impact of serum testosterone during androgendeprivation therapy in patients with metastatic prostate cancer and the SRD5A2 polymorphism. Prostate Cancer Prostatic Dis 2016;19:191-6. https://doi.org/10.1038/pcan.2016.2

25. Yasuda Y, Fujii Y, Yuasa T, et al. Do testosterone levels have prognostic significance in patients with metastatic prostate cancer treated with combined androgen blockade? Int I Urol 2015;22:132-3. https://doi.org/10.1111/iju.12623
26. Kamada S, Sakamoto S, Ando K, et al. Nadir testosterone affer long-term followup predicts prognosis in patients with prostate cancer treated with combined androgen blockade. J Urol 2015;194:1264-70. https://doi.org/10.1016/i.juro.2015.03.120

27. Klotz L, $O^{\prime}$ Callaghan C, Ding K, et al. Nadir testosterone within first year of androgen-deprivation therapy (ADT) predicts for time to castration-resistant progression: A secondary analysis of the PR-7 trial of intermittent vs. continuous ADT. J Clin Oncol 2015;33:1151-6. https://doi.org/10.1200/JC0.2014.58.2973

28. Perachino $M$, Cavalli V, Bravi F. Testosterone levels in patients with metastatic prostate cancer treated with luteinizing hormone-releasing hormone therapy: Prognostic significance? BJU Int 2010;105:648-51. https://doi.org/10.1111/i.1464-410X.2009.08814.x

29. Wang $Y$, Dai B, Ye DW. Serum testosterone level predicts the effective time of androgen deprivation therapy in metastatic prostate cancer patients. Asian J Androl 2016;Epub 2016 Mar 11. https://doi.org/10.4103/1008-682x.174856

30. Morote J, Orsola A, Planas J, et al. Redefining clinically significant castration levels in patients with prostate cancer receiving continuous androgen deprivation therapy. J Urol 2007;178:1290-5. https://doi.org/10.1016/i.juro.2007.05.129

31. Pickles T, Hamm J, Morris WJ, et al. Incomplete testosterone suppression with luteinizing hormonereleasing hormone agonists: Does it happen and does it matter? BJU Int 2012;110:E500-7. https://doi.org/10.1111/i.1464-410X.2012.11190.x

32. Tombal B, Cornel E, Matveev V, et al. Clinical outcomes and testosterone levels following continuous androgen deprivation in patients with relapsing or locally advanced prostate cancer: A post-hoc analysis of the ICELAND study. ESMO Congress 2016;7-11 0ctober 2016, Copenhagen, Denmark: Abstr 742P.

33. Saad F, Chi KN, Finelli A, et al. The 2015 CUA-CUOG guidelines for the management of castration-resistant prostate cancer (CRPC). Can Urol Assoc J 2015;9:90-6. https://doi.org/10.5489/cuai.2526

34. Soga N, Kageyama T, Ogura Y, et al. Clinical effect of switching from a luteinizing hormone-releasing hormone agonist to an antagonist in patients with castration-resistant prostate cancer and serum testosterone level $\geq 20 \mathrm{ng} / \mathrm{dl}$. Curr Urol 2016;9:31-5. https://doi.org/10.1159/000442848

35. Klotz L, Toren P. Androgen-deprivation therapy in advanced prostate cancer: Is intermittent therapy the new standard of care? Curr Oncol 2012;19:S13-21. https://doi.org/10.3747/c0.19.1298

Correspondence: Dr. Laurence Klotz, Sunnybrook Health Sciences Centre, Toronto, ON, Canada; Laurence.Klotz@sunnybrook.ca

\title{
To answer the three multiple-choice questions associated with this review article, go to:
}

\author{
https://www.qzzr.com/c/quiz/330778/want-to-claim-section-3-self-assessment-credits- \\ for-reading-cuaj-copy
}

This program is an Accredited Self-Assessment Program (Section 3) as defined by the Maintenance of Certification Program of The Royal College of Physicians \& Surgeons of Canada, and approved by the Canadian Urological Association. Remember to visit MAINPORT (www.mainport.org/mainport/) to record your learning and outcomes. You may claim a maximum of 1 hour of credit. 